\title{
Local Tourism Perception on Soda Water Tourism Objects in Indonesia: An Interview
}

\author{
Yulia Kurnia Sari Sitepu, Tio R.J. Nadeak, Rina Kesia Silaban \\ Institut Agama Kristen Negeri Tarutung \\ E-mail address yuliasitepu220782@gmail.com
}

\begin{abstract}
The Soda Water local Tourism in Parbubu Villages is natural water resources. Natural soda water is only two in the world, that is in Venezuela and in Indonesia. The purpose of this research is to investigate the Soda Water local tourism expectation. The research method used is qualitative. Based on the results of qualitative the local tourism founded that reality different from their expectations, including service, hospitality, security, and insufficient souvenir. Hopefully, soda water tourism becomes well known at home and abroad.
\end{abstract}

Keywords: Soda water, local tourism

\section{INTRODUCTION}

Tourism in the city of Tarutung is one of the interesting destinations that will be visited by local and foreign tourists. Asoda water is located at the side of the mountain, in the village of Parbubu I, North Tapanuli district, North Sumatra Indonesia, which was discovered by Minart Sihite in 1973. There is only two soda water tourism in the world that is located in Venezuela and Indonesia. The most attractive of Soda water in Indonesia the water contains foam. So the soda water has a lot of benefits, such as treating scabies, rheumatism, go out, and to cure people who have problem with eyes. Soda Water, the natural tourism of Tarutung, has been discussing for a long time. The purpose of this paper is to investigate the Soda Water local tourism expectation. According to Boeree 2005: 516 defines expectations as a pleasure that is not constant, which arises from the idea of something in the future or the past about the problem. Sometimes they worry when they detect the possibility of pleasure in an uncertain situation that is contrary. Then we feel hope.

\section{RESEARCH METHODOLOGY}

Research sites

The location of the research is in the village of Parbubu I, Tarutung District, North Tapanuli Regency, which had a distance of one kilometer from the city of Tarutung. According to regional statistical data, the village of Parbubu I is included in the developing category. The geographic area of the Village is $4.75 \mathrm{~km} 2$, the altitude of the village is $966 \mathrm{~m}$ above the sea surface. Soda water tourism is administratively included in the village of Parbubu I, which is better known by tourists in the North City area.

\section{Research Approach}


The study used a qualitative research method. Qualitative research is a particular tradition in social science that fundamentally depends on human observation in its own area and dealing with people in language and in terms. (Kirk and Miller in Moleong, 2005) As Boeree expressed that expectation as a pleasure that is not constant, which arises from the idea of something in the future or the past about the problem we sometimes worry about when we detect the possibility of pleasure in an uncertain situation that is opposite, then we feel hope (Boeree, 2005: 516). Based on this point of view, then a female tourism psychology study approach is used to the expectations of water tourism destinations as the prevailing theory if we look at the standards set by the government regarding a tourist location that should be applied to soda water tourism destination itself. Based on theGovernmentregulationRepublic of Indonesia No. 50 of 2011 concerning with the National Tourism Development Master Plan 20102025 chapter 28 verse $h$ that the Sapta pesona consists of seven elements, namely, (1) safe, (2) orderly, (3) clean, (4) cool, (5) beautiful, (6) friendly, and (7) memorable.

Indonesia is well known as a rich country in the tourism field, both land, and marine tourist. This wealth can be made as one of the assets as a source of Indonesia's income. The tourism asset has not been managed well yet. The tourism sector as an economic activity had been a potential mainstay and to be the priority of other countries. Indonesia has various attractive tourism objects. Geography is an important factor to be considered for developing tourism. Climate differences influence several natural geographic and culture; hence developing tourism areas need to be maintained (Sujali, 1989).

Tourism is one of the tools to control physics development in order to keep the ecology balance as a result of economic benefit (Myra P. Gunawan, 2007). Essentially, tourism is a part of society's culture, geographic phenomena; therefore, the government must consider the urban and territorial layout.

Tourism is the phenomena and relation of unity from tourist interaction, business, government. Tourism development such as how to serve a satisfying object in order to give a positive effect on marketing tourism product in the future. Tourism objects classification. Directorate general of tourism (1985) assumed that tourism classification consists of some objects.

\section{Natural resources}

Tourism objects such as panorama, mountains, beach, flora, and fauna.

\section{Cultural resources}

Cultural resources such as traditional dances, art, traditional ceremony, religious ceremony, and funeral

\section{Man-made resources}

This object is influenced by human activities such as a museum, worship place, tourist area music player.

Tourism in the city of Tarutung is one of the interesting destinations that will be visited by local and foreign tourists. Soda water is located at the side of the mountain, in the village of Parbubu I, North Tapanuli district, North Sumatra Indonesia, which was discovered by Minart Sihite in 1973. There is only two soda water tourism in the world that is located in Venezuela and Indonesia. The most attractive of Soda water in Indonesia the water contains foam. So the soda water has a lot of benefits, such as treating scabies, rheumatism, go out, and curing people who have problems with eyes. Soda Water, the natural tourism of Tarutung, has been discussing for a long time. The purpose of this paper is to investigate the Soda Water local tourism expectation. According to Boeree 2005: 516 defines expectations as a pleasure that is not constant, which arises from the idea of something in the future or the past about the problem. The tourist expectation toward the Soda water such as a number of parking areas or protected area. Sometimes they worry when they detect the possibility of pleasure in an uncertain situation that is contrary. Then we feel hope.

Perception is the process of how did the individual chooses, organizes, and interprets the information to create a meaningful world image. Perception is not only related to physical stimulus but also links to 
the environment surrounding. Visitor's perception is the evaluation or view of a visitor toward something. The quality of tourist destinations has to be increased to a better level to achieve a positive perception.

Perception in the tourism field is an opinion or a point of view of a visitor in understanding a tourism destination. In the tourism industry, every tourist has a different personality. Hence in evaluating the phenomenon, they have their own opinion. Tourist perception is an important thing in developing tourism destination dealing with what they expect, want, interest. Perception is the process of how an individual selects, organizes, and interprets information input to create a meaningful picture of the world. Perception does not only depend on physical stimuli but also on stimuli related to the surrounding environment and the condition of the individual concerned (Setiadi, 2003: 92).

There are several conditions for a perception, according to Bimo Walgito (1997: 54), namely, as follows:

a. There are objects that must be perceived.

b. There are sensory organs or receptors (tools to receive a stimulus)

c. There is attention, which is the first step in preparation for creating the perception.

d. Perception is often called opinion, attitude, judgment.

Perception is defined as "a process that is preceded by sensing," which is a process that leads to the center of the nervous system, namely the brain, so that the individual is aware of what is seen, what is heard. Therefore the sensing process will always occur when the individual receives a stimulus (Walgito, 2003: 53).

Perceptual aspects, according to Bimo Walgito (2003: 128), namely:

\section{Cognitive aspects}

This component is composed of the knowledge or information a person has about the object. Relating to one's mind what is in the mind of the consumer. Cognitive is rational, makes sense.

\section{Affective aspects}

The affective component is related to pleasure and displeasure, so it is evaluative in nature which is closely related to cultural values or its value system. Relating to feelings are emotional. It can be in the form of feelings of joy, sadness, cheerfulness, and joy.

3. The cognitive aspect

It is a person's readiness to behave in relation to the object of his attitude. Relating to action. His form is a person's actions towards his object.

The visitor's perception is the visitor's assessment or view of something. A tourist object must improve the quality of the object for the better in order to get a positive perception. Perception in the world of tourism is the opinion or point of view of visitors and tourists in understanding a tourist destination. In the tourism industry, every tourist has a different personality each so that they see the existing phenomena they have their respective perceptions.

The perception of tourists is one of the important things in the development of a tourism destination. Regarding what visitors want, want, and expect from a destination is very important in terms of marketing tourist objects (Warpani, 2007)

\section{The Scope of Research}

The limitation of the study to know the tourist's expectations toward Soda water. 


\section{Research Subjects and Objects}

The subjects of this study were local tourists who were selected as sources of data with qualitative research methods. The object of this research focused on local tourists' expectations, the factors that influence their expectations, as well as the facts seen from the level of satisfaction of tourists who have visited soda water tourism destinations. Furthermore, we will see whether the impact of the realization of expectations that have been built as a tourist in the concept of thinking about a donation can become a promotional media.

\section{The technique of Data collection}

The technique of data collection was primary data and secondary data. To collect primary and secondary data, researchers use several data collection techniques, namely:

1. Observation is a systematic observation and recording of the observed phenomena. Data collection in this study was carried out by means of direct observation and as a researcher who placed him as an observer (recognized outsider) so that research interaction with research subjects was limited. By observing, the researcher records what they see and replaces to be written documentation to provide a complete picture of the object to be studied.

2. Interview, This research conduct by depth interview. The researcher interviewed a participant who often visited Soda Water and proposed the participant about seven questions, and the interview took place as long as 30 minutes. According to the participant, Soda Water is a nice place to visit even though some facilities Have not adequate yet.

3. Documentation is a method of collecting data through written remains, especially in the form of archives, including books, official documents, and statistics related to research problems. This technique is used by means of conducting a review of the written materials.

\section{FINDING AND DISCUSSION}

Public expectations of soda water tourism objects from various aspects:

\section{Service}

Service can be interpreted as a way that is done by an individual/someone in meeting the needs of his guests, by devoting all his abilities, feelings, and skills so that the satisfaction felt by the person being served is achieved. One of the characteristics of service is the expectation/ expectation of tourists, which are integrated into tourism products. If judging from the tourism products available at tourist spots, soda water is still very limited. In terms of food products, there is only a very limited food menu, and the taste is not too good either. The tourists hope that the food products offered or provided are more varied and have a high taste. Because this tourist attraction is a water tourism object where the main activities carried out are bathing, swimming. After swimming/bathing, tourists will generally feel cold and hungry. Food products are a mainstay of services that can meet the needs of tourists. Meanwhile, in terms of souvenir products, there is also very little in the location of tourist attractions where there is only a small shop which, when viewed in terms of goods sold, does not vary and the quality of the goods is also not very good. Tourists hope that there will be a market/shopping center provided in the location that sells local specialty products sold by various shops. Meanwhile, the service process in the form of hospitality is also not very good, where tourists do not get welcome by the tourist attraction. And tourists do not have the opportunity to communicate with the tourist attraction to get more information about the soda water attraction. Hopefully, the stakeholders involved in the management of soda water tourism objects can improve services that are of higher quality so that this tourist attraction becomes one of the recommended tourist objects that can meet tourist satisfaction. 


\section{Order}

Order is a condition or condition that reflects an orderly and orderly atmosphere and discipline in all community life. An orderly situation or atmosphere is needed in managing and dealing with tourists. An orderly atmosphere is also one of the things needed to satisfy tourists. Orderliness is generally more aimed at the order from a regulatory perspective. The hope of tourists, the atmosphere at the soda water tourism location is orderly with the existence of regulations that are more disciplining for tourists. After making observations at soda water tourism sites, it turns out that no regulations have been found that create an orderly atmosphere at soda water tourism sites. The regulations should be applied in this tourist location, such as in terms of clothing in a soda water pool, namely the use of swimsuits, in terms of time in the form of open-close schedules, in terms of cleanliness in the form of not littering anywhere around soda water tourist sites and bathing without using soap and shampoo in the pool because public bathrooms are provided. Using shampoo and soap in the pool will cause water pollution, which reduces the cleanliness of soda water in the pool. There are still many things that can be addressed with other regulations that improve orderliness at tourist sites so that tourists feel satisfied and want to come back to tourist sites. The coordinator had strived for keeping orderly but to create orderly must be supported by some facilities, even if the coordinator already strengthen out the orderly but the come out is not adequate because of the location of Soda water lack of facilities such as a toilet.

\section{Security}

Soda water is very comfortable. The manager prepares some workers to watch the visitor, so the condition of the Soda Water location is secure.

\section{Cool}

A state of cool is a condition that provides freshness. Soda water tourism lies between Rura Silindung valley and Bukit Barisan mountainous range, so the Soda Water condition is very cool. This attractive condition invites the visitor to come to Soda Water.

\section{Beautiful}

Feel at home in one of the targets of Soda Water s coordinator, so the beauty of Soda Water is very wonderful and natural. Sites Barita hill and Salib Kasih support the existence of Soda Water. The mountainous area provides original beauty.

\section{Friendly}

Generally, Indonesian society is called as friendly people in the world, due to the Indonesian existence as a tourism country. Indonesia, famous for a lot of cultures, so to be polite is the most important principle to keep the unity of Indonesia, which consists of thousands of tribes. Especially in the Soda Water location, the coordinator, apply friendly to be polite to the visitors.

\section{Memorable}

The tourist closely relates memorable to souvenir take home. Nevertheless, the tourist will not get the souvenir if something caused a bad impression for them such as not good security bad experience, cleanness, the tourism object is not beautiful, fewer facilities, and the tourist does not get the easy access to the tourism destination.

Soda Water must be a memorable tourism destination for many tourists in the world. Since Soda Water is the only two, which exist in the world, Indonesia, as the location of Soda Water, must make the Soda Water become a priority in development and reservation.

There are many factors that supported the Soda Water is memorable. However, some others, such as facilities, accessibility, and amenity still inadequate. 


\section{CONCLUSION AND SUGGESTION}

Based on the problem formulation, the result of the research, and discussion, it can be concluded that perception toward Soda Water, the tourist feels dissatisfied. This is evidenced by the presents of tourist complaints who have visited Soda Water, and even there are so many complaints of Soda Water tourists, but the coordinator never improved their tourism village. The researcher contributed to the Ministry of Tourism to explore and guide the tourism communities in developing tourism area by applying sapta pesona (seven enchantments) in increasing the number of a comfortable local tourist destination. For the next researchers, they are suggested to conduct research about the effectiveness of applying Sapta Pesona in another tourism village.

\section{REFERENCES}

Aydin, B., \& Emeksiz, M. (2018). Sustainable urban tourism success factors and the economic performance of small tourism enterprises. Asia Pacific Journal of Tourism Research , 1-988. 106.

Colea, S. (2014). Tourism and water: from stakeholders. Journal of Sustainable Tourism, 1-

Desbiolles, F. -H., Carnicelli, S., Krolikowski, C., Wijesinghe, G., \& Boluk, K. (2019). Degrowing tourism: rethinking tourism. Journal of Sustainable Tourism, 1-19.

F.H Pang, S., McKercher, B., \& Prideaux, B. (2012). Climate Change and Tourism: An Overview. Asia Pacific Journal of Tourism Research , 1-20.

Henkel, R., Henkel, P., Agrusa, W., Agrusa, J., \& Tanner, J. (2006). Thailand as a tourist destination: Perceptions of international visitors and Thai residents. Asia Pacific Journal of Tourism Research, $1-287$.

Higgins, F. (n.d.).

Lee, S., Kline, C., \& Leec, G. (2013). Perceived Impact of a Naval Base on a Tourism Destination. Asia Pacific Journal of Tourism Research, 1-845.

Lugosi, P. (2008). Hospitality spaces, hospitable moments: consumer encounters and affecctive experiences in commercial settings. journal of foodservices , 139-149. 